\title{
Index of works by Cixous
}

1938, Nuits 171

Une autobiographie allemande 47

Ayaï! Le cri de la littérature (Ay yay! The Cry of Literature) 64

'Bathsheba, or the Interior Bible' 22-3

The Blindfolded Fiancée 56

'The Book as One of Its Own Characters' 192

'The Book I Don't Write' 184-90

The Book of Promethea 218, 229 n.54

'The Character of "Character"' 8, 120, 124-5, 192-3, 197

'Cixous on the Telephone' 217-18

'Coming to Writing' 7, 26, 87 n.13

The Day I Wasn't There (Le jour où je n'étais pas là) 83, 126-7, 216-17, 221-3

Death Shall Be Dethroned 49

Défions l'augure 204 n.13

Double Oblivion of the Ourang-Outang 211, $225 \mathrm{n} .18$

Dream I Tell You (Rêve je te dis) 3, 30, $35-50,69,131$

Encounters (Rencontre terrestre) 4, 125, 162-3, 171, 191, 200, 203 n.8, 226 n.29

Eve Escapes 53-4

The Exile of James Joyce 8, 219-20

'Fiction and Its Phantoms' 21, 32-3 n.31, 54-5, 105-9, 158-60

FirstDays of the Year (Jours de l'an) 23, 32 n.17, 152, 156-7, 159-60, 163, 165, 171, $172,175,214$
'The Flying Manuscript' ('Le manuscrit volant') 218

'From the Word to Life' 28, 207

'Guardian of Language' 214

Hemlock (Ciguë) 5, 87-8 n.16

Hyperdream 53-4, 73-4

'In the beginnings there were many...' 54

Inside (Dédans) 30

Insister of Jacques Derrida 155, 225 n.20

'Introduction to Lewis Carroll' 110-13

“"A Kind of Magic"' 9-11

'Language is the Only Refuge' 185

'The Laugh of the Medusa' 11, 21, 25, 80-1

'Literature Suspends Death' 47, 212

Los, A Chapter 4, 24, 49-50, 62-4, 69-74, 195-6, 214

Love Itself in the Letterbox 53-4

'Love of the Wolf' 53

“"Mamãe disse ele", or Joyce's second hand' 93-4

Manhattan 53, 89

Manna for the Mandelstams for the Mandelas 205 n.39, 219, 220

Mother Homer is Dead... 3, 188, 193, 211

Neutre 58

The Newly Born Woman 21, 48

'The Novel Today' 158

OR: les lettres de mon père 178 n.30, 269 
'The Play of Fiction' 5, 119, 155, 209

Portrait of Jacques Derrida as a Young Jewish Saint 79, 104-5, 125, 212

Le Prénom de Dieu 157, 190-1, 210

Reading with Clarice Lispector 227 n.37, 227 n. 38

Reveries of the Wild Woman (Les rêveries de la femme sauvage) 100-3, 136-7, 228-9 n. 49

'Rites of Tenderness, Killing the Dead, Living On' 26

Rootprints 31 n.4, 69, 120, 155

'Shakespeare Ghosting Derrida' 170, 179 n. 57

'Shared at Dawn' 218

'Sorties' 21, 47-9, 81-2, 91, 97, 139, 153, 158, 221

'Stigmata, or Job the Dog' 24, 29
Three Steps on the Ladder of Writing 19, 26, $28,54,69,78-80,83,85-6,117,118$, $147-8,174$

Tombe 29

'The Unforeseeable' 176 n.8

'We Must Hand Our Inheritance On' 209

'What is it o'clock?' 104, 107, 110

'Without end' 13-14, 212

'Writing Blind' 19, 22, 25, 56, 83, 89-93, $117,129,157 \mathrm{n} 8,159,162,165$, 213-14

'You race towards that secret, which escapes' 89,91

Zero's Neighbour (Le voisin de zéro) 154 , $156-7,170$ 